\title{
SEGURANÇA DO TRABALHO NO PROCESSO DE CORTE DE CANA-DE AÇÚCAR PARA A ALIMENTAÇÃO DE GADO
} DE CORTE

Congresso Nacional Online de Empreendedorismo, 3ạ edição, de 06/12/2021 a 08/12/2021 ISBN dos Anais: 978-65-81152-30-7

SOUZA; Roberta Marinho de ${ }^{1}$

\section{RESUMO}

Introdução/ contextualização: O empreendedor rural é aquele que realiza a gestão de sua propriedade rural, buscando fazer com que esta seja a mais eficiente possível. Dentro dessa visão, têm-se os colaboradores que são fundamentais para que o trabalho gere estes frutos esperados. Este estudo teve como foco um micro empreendimento rural, onde apresentava como resultado das atividades realizadas uma pequena produção de gado de corte. Considerando que essa atividade além de ser regulada pela CLT (capítulo $V$ ) também possui especificações na Norma Regulamentadora 31, dentre as outras NRs. Objetivos: Os objetivos principais deste trabalho é melhorar as condições de trabalho de um empreendedor rural, que realiza o corte manual de cana-de-açúcar (responsável por compor boa parte da alimentação nutricional do gado) buscando identificar os principais riscos que este trabalhador se expõe quando realiza essa atividade. Método: O presente estudo foi composto por pesquisa bibliográfica (através de consultas em livros e artigos) e estudo de caso em uma pequena propriedade rural, neste foi empregado como ferramenta para auxiliar o processo de identificação de riscos a Análise Preliminar de Risco (APR), entrevista e checklist. Resultados: Após analisar a atividade realizada pelo proprietário rural identificou-se que está atividade exige esforço muscular e repetitividade. Logo, foi possível detectar a presença dos riscos físicos (gerados pelo esforço de corte e movimentação de cana cortada, risco do calor), riscos ergonômicos (gerado pela postura irregular durante o trabalho) e riscos biológicos (presença de animais peçonhentos). Algumas das propostas elaboradas para mitigar/solucionar esses riscos foram realizar paradas curtas e frequentes, já que o trabalho realizado exige esforço muscular, hidratação, utilização de vestimentas de cor clara e realização destas atividades se possível no período/horário mais fresco do dia. Redução do peso movimentado e modificação da forma como ele era transportado. Também foi identificado que este possuía e utilizava alguns equipamentos proteção individual (EPIs) considerados na NR 06, no entanto, desconhecia o uso do dispositivo de proteção pessoal indicado na NR 31 (perneira para uso visando proteção contra picada de animais peçonhentos).Conclusão ou considerações finais: Sendo assim, os objetivos do estudo foram atendidos, trazendo melhores condições para a realização da atividade deste empreendedor rural. Além de demonstrar a importância da Segurança do Trabalho e da Ergonomia para a melhoria das condições do trabalho.Garantindo a sua segurança e também o 
aumento da produtividade, já que estudos comprovam a diminuição da produtividade quando o trabalhador realiza seu trabalho de forma consecutiva, sem realizar as paradas necessárias.

PALAVRAS-CHAVE: Análise Preliminar de Risco, atividade de corte de cana-deaçúcar, Empreendedorismo Rural, Ergonomia, Segurança do Trabalho no Campo 